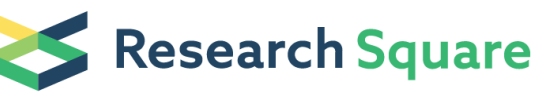 \\ Preprints are preliminary reports that have not undergone peer review. \\ They should not be considered conclusive, used to inform clinical practice, or referenced by the media as validated information.
}

\section{Eocene-Oligocene terrestrial cryospheric processes: bipolar glaciation and uplifted Tibet}

\section{Guoqing Xia}

State Key Laboratory of Oil and Gas Reservoir Geology and Exploitation, Institute of Sedimentary Geology, Chengdu University of Technology \Chengdu University of Technology, China

Chihua Wu ( $\nabla$ wuchi-hua@foxmail.com )

State Key Laboratory of Oil and Gas Reservoir Geology and Exploitation, Institute of Sedimentary

Geology, Chengdu University of Technology \Chengdu University of Technology, China

Juan Pedro Rodríguez-López

Calle Mascaraque, 48, 2_A, Madrid, 28044, Spain

\section{Ahmed Mansour}

Geology Department, Faculty of Science, Minia University, 61519 Minia, Egypt

\section{Xin Jin}

State Key Laboratory of Oil and Gas Reservoir Geology and Exploitation, Institute of Sedimentary Geology, Chengdu University of Technology $\mathbb{}$ Chengdu University of Technology, China

\section{Junling Pei}

Institute of Geomechanics, Chinese Academy of Geological Sciences

\section{Haisheng Yi}

Institute of Sedimentary Geology, Chengdu University of Technology

\section{Gaojie Li}

College of Resources and Environmental Engineering, Mianyang Normal University, 621000 Mianyang, China

\section{Qiushuang Fan}

Institute of Sedimentary Geology, Chengdu University of Technology, Chengdu 610059, China

\section{Zhiqiang Shi}

State Key Laboratory of Oil and Gas Reservoir Geology and Exploitation, Institute of Sedimentary Geology, Chengdu University of Technology $\mathbb{}$ Chengdu University of Technology, China

\section{Article}

Keywords: Frost structures, Glaciation, Ice-rafted debris, Eocene, Tibetan Plateau

Posted Date: August 23rd, 2021

DOl: https://doi.org/10.21203/rs.3.rs-835656/v1 
License: (c) (i) This work is licensed under a Creative Commons Attribution 4.0 International License. Read Full License 


\section{Abstract}

There is no agreement regarding the processes that have governed the birth and vanish of ice masses on Earth during Cenozoic, as well as the possible existence of unipolar vs bipolar glaciations which remain controversial. Although it is generally accepted that Cenozoic cryosphere was characterized by a unipolar Antarctic glaciation at the Eocene-Oligocene Transition ( $34 \mathrm{Ma})$, recent investigations suggest synchronous cryospheric processes at both hemispheres at this time. Here we present the first worldwide evidence of ice-related structures in Eocene-Oligocene sediments from the mid-latitude Lunpola Basin of central Tibet. The lacustrine deposits contain two intervals dated 37.8-35.6 and 34.0-32.5 Ma, respectively, which preserve seasonal frost events, glendonites and ice-rafted debris. These cryospheric processes were synchronous with two recorded stratigraphic intervals containing ice-rafted debris along offshore Greenland and in the Arctic region. Our results provide robust continental evidence of EoceneOligocene bipolar glaciation and a direct evidence for an already uplifted central Tibet during late Eocene. This finding brings into debate the timing and magnitude of inherited elevation of the vast proto-Tibetan Plateau before the continental collision between India and Eurasia.

\section{Main}

Widespread mountain glaciations on Earth are thought to have occurred no earlier than the Miocene and Pliocene $^{1}$, and the Eocene-Oligocene Transition (EOT) is thought to have only been characterized by unipolar Antarctic glaciation ${ }^{1,2}$. However, increasing evidence indicates that Eocene-Oligocene polar ice existed in the Northern Hemisphere (e.g. ref. ${ }^{3-5}$ ). These Cenozoic glaciations are largely inferred from marine sediments, whereas continental sedimentary archives of glaciations are relatively rare ${ }^{5}$. Identification of continental sediments that preserve seasonal frost events and contain glendonite and ice-rafted debris during the EOT in the central Tibet is challenging. The almost constant occurrence of frost marks has a late Eocene to early Oligocene age of between 37.8-32.5 Ma (Priabonian to Rupelian), based on our zircon U-Pb age and fossil data, magnetostratigraphic and chemostratigraphic and lithostratigraphic correlations (Supplementary Information). Thus, the ice-related structures in the studied succession record terrestrial cryospheric processes during the EOT.

The recognition of ice-related structures, cryospheric processes, and cold-water authigenic minerals in lacustrine deposits from plateau settings provides key paleoclimate evidence for past ice-related processes ${ }^{6}$. Determining the onset of glaciations is widely based on direct paleoclimate proxies, including the occurrence and geochemistry of ice-rafted debris $(\mathrm{IRD})^{7-9}$, oxygen isotope data ${ }^{2,10-11}$, and identification of microfossil species that live close to sea ice ${ }^{9,12}$. Other proxies are based on major element geochemistry that are affected by chemical weathering ${ }^{13,14}$. Thus, we used the chemical index of alteration (CIA) along with the oxygen isotope data and clay mineralogy from these Eocene-Oligocene lacustrine deposits to reconstruct the intensity of chemical weathering and related climate state at this time. The study area lies in the Lunpola Basin, which is a Cenozoic continental basin in central Tibet, southwestern China, and is situated in the Bangong-Nujiang suture zone formed by the Mesozoic 
collision of the Lhasa and Qiangtang blocks (Fig. 1a) ${ }^{16}$. During the EOT, the central Tibet was located in a transitional semi-arid setting and was sensitive to the Asian winter and summer monsoons and Westerlies $6,16,17,18$.

Here, we provide the first report of frost marks, glendonite, and IRD in upper Eocene to lower Oligocene lacustrine rocks from the Lunpola Basin. This evidence demonstrates the occurrence of persistent freezing waters during lacustrine sedimentation, and enables comparisons with Eocene-Oligocene glacial features in the Arctic and offshore Greenland. Our results have global implications for terrestrial EoceneOligocene cryospheric processes. In addition, the timing and magnitude of the uplift of the Tibetan Plateau related to the India-Eurasia collision controlled the initiation and evolution of several Cenozoic global events, including late Eocene Asian climate cooling ${ }^{17,19-21}$ and the onset of the Asian monsoonal system $^{22,23}$. Our results provide a more direct spatial-temporal constraint for regional climate system and its possible response to Tibetan landscape evolution.

\section{Ice-related Structures In Central Tibet}

Three key ice-related structures are found in the Niubao Formation of Sect. 382 along the Zhajia Zangbo River in the western Lunpola Basin (Fig. 1-b and Supplementary Fig. 1-a,b). The first ice-related structure is the most common and occur on bedding planes, which are characterized by radiating, lace-like, dendritic, and feather-like shapes typical of ice crystals (Fig. 2a-b, f-g). These marks are straight limits and lineation diverting from a sharp lineation and radial patterns from nuclei, exhibiting geometrical affinities typical of modern frost structures (Fig. 2a-g). Some marks are slightly curved and elongate. They are typically $2-5 \mathrm{~cm}$ across (up to $50 \mathrm{~cm}$ ), 2-5 $\mathrm{mm}$ in width, often linked and branch into each other under a recurrent pattern, with a uniform angle $\left(<30^{\circ}\right)$ between branches. The intermittent occurrence of these frost casts on bedding planes indicates that the Lunpola lake basin experienced strong seasonal temperature variations, and that winter was characterized by water temperatures below $0^{\circ} \mathrm{C}$.

The second ice-related feature is stellate displacive structure that is characterized by euhedral blocky carbonate crystals showing a displacive growth in the laminated sediments (Fig. 2h-I). Stellate displacive structures are usually interpreted as glendonite pseudomorphs of ikaite $\left(\mathrm{CaCO}_{3} \cdot 6 \mathrm{H}_{2} \mathrm{O}\right)$, a common cryogenic mineral indicative of freezing temperatures ${ }^{24}$. Glendonite is one the most common indicators of near-freezing settings and is widely used in paleoclimate reconstructions ${ }^{25}$. The glendonite occurs as stellate clusters or aggregates with pyramidal crystal faces that are $0.1-1.5 \mathrm{~mm}$ in size and occasionally have interior voids (Figs. 2j and Supplementary Fig. 5-c). In cross-section the crystals are block- or rhombshaped (Fig. 2k). Penetrative star-shaped twins are also common and characterized by obtuse angles (95-125; Fig. 2l). Based on the sedimentary laminae that are warped around the glendonite (Fig. 2i-j and I), we speculate that precursor minerals were converted to glendonite during early diagenesis, and prior to sediment compaction and cementation and that these minerals grew displacive in the host laminated sediments. 
Ikaite pseudomorph morphologies include square prismatic and pyramidal habits, and multiple crystals can form a sigmoidal shape ${ }^{25}$. Ikaite is metastable near Earth's surface, and is thermodynamically stable at near-freezing temperatures. Ikaite crystals often occur as aggregates of bipyramidal crystals after the transformation of ikaite to aragonite, calcite, or vaterite by rapid dehydration with increased ambient temperatures ${ }^{24,26}$. Glendonite and its pseudomorphs have been widely reported in the sedimentary record from relatively deep marine to tidal and lacustrine environments ${ }^{26,27}$. Glendonite has been also documented in modern marine sediments deposited at low temperatures $\left(-1.9\right.$ to $\left.+3.0^{\circ} \mathrm{C}\right)$, such as in the circum-Arctic and Antarctic regions ${ }^{26,27}$. Therefore, the repeated occurrence of glendonite, consistent with other ice-related structures, supporting a short-lived sharp plunge in temperatures to frozen and/or cold setting during deposition of the Niubao Formation.

Angular and sub-rounded dropstones and outsized clasts (coarse to fine sand) encased in laminated sediments of the Niubao Formation are another ice-related structures (Fig. 2m-p). They have deformed the underlying and overlying sediments, including bending (Fig. 2n), rupture, and penetration structures at their base (Fig. $2 \mathrm{~m}$ ), and drape and onlapping structures on their upper surfaces. They are widely scattered in the laminated sediments and are associated with glendonite (Fig. 2o-p). Their occurrence disrupted the lower contact and onlapping geometries of lamination, suggesting that the clasts sunk to the lake bottom from a certain water depth, deformed the underlying sediments, and were then covered by laminated carbonate ${ }^{28}$. The outsized clasts are interpreted as IRD formed by gravitational sinking of debris originally attached to the bottom of lacustrine ice floes, which sunk when the ice melted and thus formed dropstones in the lake sediments ${ }^{29,30}$. The Eocene dropstones have inclined penetrative geometries in the underlying deformed sediments, similar to IRD reported in Proterozoic rocks from India ${ }^{30}$.

\section{Geochemical And Mineralogical Proxies Of Paleoclimate}

Our fieldwork revealed that ice-related structures are largely restricted to the gray dolomite and argillaceous dolomite strata (Fig. 3). These observations suggest that the formation of gray dolomite with freeze-related sedimentary structures was controlled by intermittent glaciations, whereas the dolomitic siltstone was mainly deposited in non-freezing and/or warming conditions. This is in agreement with the CIA values, which exhibit significant stratigraphic variations throughout the studied section, with the lowest values at the EOT-1 and Oi-1 (Fig. 3; for more details, see SI). During the EOT, CIA values varied between 55-60 in most of the (argillaceous) dolostones and 65-70 in the dolomitic siltstones, suggestive of a weak to moderate weathering intensity in the source areas, respectively ${ }^{13,14}$. Thus, the lower CIA values $(<60)$ in the Niubao Fm. are consistent with multiple cooling events and semiarid climate conditions, whereas higher values $(>60)$ reflect warmer and semi-humid climate conditions. Further insights into the climate at this time can be gleaned from the clay mineralogy, whereby illite and chlorite are predominant under low-weathering, cool, and/or arid climate conditions, and smectite and kaolinite contents increase during periods of enhanced weathering intensity and temperate-humid climate conditions $^{37}$. In the studied section, illite and illite/smectite mixed layers (I/S) are very prevalent and 
smectite and kaolinite are absent in most samples. The (smectite $+\mathrm{I} / \mathrm{S}) /$ illite ratio can be used to trace the silicate weathering index ${ }^{38}$. Here, low values of $($ smectite $+\mathrm{I} / \mathrm{S}) /$ illite ratio were recorded at most of the studied succession except for some samples from the EOT that have higher values, which are significantly consistent with the CIA.

The $\delta^{18} \mathrm{O}$ values are significantly negative throughout the studied section $(-2.05 \%$ o to $-11.15 \%$, with an average of $-5.72 \%$ o) and exhibit a similar pattern as the CIA values and (smectite $+\mathrm{I} / \mathrm{S}$ )/illite ratios (Fig. 3). During the EOT, $\delta^{18} \mathrm{O}$ values exhibit a large positive excursion from $-10.3 \%$ o to $-1.80 \%$ o at $c a$. 33.6 Ma. This positive $\delta^{18} \mathrm{O}$ excursion was accompanied by a major decrease in atmospheric $\mathrm{CO}_{2}$ from 1050 to $700 \mathrm{ppmv}^{31-35}$. It also correlates with changes in benthic foraminiferal $\delta^{18} \mathrm{O}$ records, and broadly corresponds to the Oi-1 event that was likely triggered by strong $p \mathrm{CO}_{2}$ drawdown ${ }^{39}$. Therefore, this $\delta^{18} \mathrm{O}$ excursion records a relative decrease in lake water temperature and the formation of ice-related structures in the Lunpola Basin. Although the obtained $\delta^{18} 0$ profile is similar to other published records, the extreme negative $\delta^{18} \mathrm{O}$ values were likely due to a diagenetic overprint during dolomitization ${ }^{40}$.

\section{Eocene-oligocene Bipolar Glaciation}

The EOT ( $c$ a. 34.0-33.5 Ma) was characterized by a major environmental and climatic change that lasted for ca. $790 \mathrm{kyr}$, leading to the first major glaciation in Antarctica and global cooling from a largely ice-free greenhouse to icehouse climate ${ }^{1}$. This climatic transition involved several pulses of glaciations or cold events, including the globally recognized EOT-1 and Oi-1 2,39,41. These two periods of ice sheet formation have been recognized during East Antarctic ice growth, including the EOT-1 cooling event at $33.9 \mathrm{Ma}$ that triggered the expansion of ice sheets in elevated areas, and the Oi-1 cooling event at 33.7 Ma that led to the development of ice sheets over a wide continental region ${ }^{1,28}$. However, an increasing number of studies have inferred that Eocene-Oligocene polar ice existed in the Northern Hemisphere, and thus proposed that bipolar glaciation existed at this time ${ }^{3-5}$. Our inferences from the Niubao Formation are consistent with the latest results of bipolar glaciation. Our results are based on 19 stratigraphic occurrences of ice-related structures (e.g., frost marks and IRD) and cold water-related authigenic minerals (i.e., glendonite after ikaite) recovered from the 100-m-thick interval that accumulated in $4.4 \mathrm{Myr}$ (36.9-32.5 Ma). Freezing conditions prevailed at least seasonally, leading to an exceptional record of seasonal ice-related structures produced by melting ice floes that drifted on the lake surface and growth of ikaite in the lacustrine sediments. Most of the ice-related structures occur in two intervals dated 37.835.6 and 34.0-32.5 Ma respectively, which are in the middle Priabonian and early Rupelian, and are

synchronous with two intervals of bipolar glaciation and IRD in the Greenland and Arctic regions ${ }^{3-5}$ (Fig. 3). Therefore, our terrestrial sedimentary record, along with marine archives of Greenland and Arctic sea ice, support the hypothesis of bipolar Earth glaciations during EOT.

\section{An Already Uplifted Central Tibet}


The timing and magnitude of central Tibet uplift remain controversial. The paleoelevation of the Lunpola Basin has been estimated from pedogenic carbonate $\delta^{18} \mathrm{O}$ values, which indicate it was elevated to $\sim 4.5$ $\mathrm{km}$ at $>35 \mathrm{Ma} \mathrm{ago}^{42}$. Between 45 and $30 \mathrm{Ma}$, central Tibet was at an elevation of $\sim 3 \mathrm{~km}$, and paleoelevation data support the existence of a Paleogene proto-Tibetan Plateau ${ }^{20,43}$. Our previous study indicates that a Cretaceous desert was developed in the eastern Tibetan Plateau that had already been uplifted to high altitudes and cooled, resulting in ice floe formation and dropstone accumulations in desert oases ${ }^{44}$. Therefore, the palaeoelevation invoked for the Tibetan plateau at this time could be, in part, inherited from the Cretaceous period, whereby the Lunpola Basin might have palaeoelevation of 4.5 $\mathrm{km}$ in the early Eocen $\mathrm{e}^{43}$. In contrast, revised magnetostratigraphic data ${ }^{38}$ and paleontological data ${ }^{45}$ from the Lunpola Basin suggest that the basin floor was $<2.3 \mathrm{~km}$ and bounded by high mountain systems ( $>4 \mathrm{~km}$ ) at ca. 39.5-37.0 Ma. While the former high elevations of $\sim 4.5 \mathrm{~km}^{42}$ at $>35 \mathrm{Ma}$ ago based on paleosol carbonate $\delta^{18} \mathrm{O}$ are reconstrained to the interval of $\sim 26.5$ to $21.5 \mathrm{Ma}^{38}$. This result is consistent with the late Oligocene to Miocene paleoelevation estimates ( 3.0-4.5 km) for the Lunpola/Nima basins (for more details, see SI). As such, based on these previous studies, Lunpola Basin would have been at a lower elevation $(<2.3 \mathrm{~km})$ before the EOT and a relatively higher elevation $(\sim 3.0-4.5$ km) during the Miocene (Fig. 4).

We find that the Lunpola Basin experienced freezing conditions on a regular occurrence, probably seasonally between 37.8-32.5 Ma, although such processes are occurring today in the Badain Jaran desert at altitudes of 1200-1700 $\mathrm{m}^{44}$, and have even been reported from altitudes $86 \mathrm{~m}$ below sea level in the Dead Valley playas ${ }^{46}$. However, the occurrence of glacial dropstones and glendonite indicates that freezing temperatures had to be maintained in the lake not only on a seasonal basis, but for multiple years. This suggests that the Lunpola Basin was at a higher elevation than the $\sim 2.3 \mathrm{~km}$ inferred from late Eocene paleo-botanical constraints. Otherwise, the exceptional low temperatures (e.g., cold snap/snaps, or both) were not prevalent at this time. In this regard, high mountains in present-day Asia have permanent glacier ice $(>4 \mathrm{~km})$ and permafrost $(3-6 \mathrm{~km})^{47}$. Thus, if the paleoelevation was $>2.3$ $\mathrm{km}$ in the late Eocene, then the development of seasonal frost structures, glendonite, and IRD would be expected.

An elevated plateau implies that the EOT global glaciation affected (i.e., decreased) the regional temperatures of these already glaciated high-altitude mountains surrounding the basin. This promoted the expansion of both the permafrost and glacier fronts in the surrounding areas and cooled the lacustrine waters. This is consistent with preserved plant-bearing horizons at different stratigraphic levels in the Lunpola/Nima basins (e.g. ref. ${ }^{45,48,49}$ ). The timing of the cryospheric processes discussed here and paleoecological changes inferred from these plants appear to be diachronous. Palm-bearing strata have been reported from horizons dated to 39.5 $\mathrm{Ma}^{45}$, and tropical fish ${ }^{48}$, insects ${ }^{48}$, and plant fossils ${ }^{48,49}$ have been dated to $37 \mathrm{Ma}^{38}$, whereas most of the ice-related structures were developed at 36.9-32.5 Ma, along with one short cold event at 37.8-36.9 Ma. In addition, the EOT glaciation only lasted for ca. $790 \mathrm{kyr}^{1}$, which is insufficient to explain the ice- 
related structures that formed for ca. 5.3 Myr in the Lunpola Basin. Therefore, since 37.8 Ma, the high elevation basin floor (probably $>3 \mathrm{~km}$ ) may be an underlying cause of the emergence of these cryospheric processes. It is clear that the Tibetan Plateau was not a vast plain at sea level in the Paleogene, but displayed considerable topographic relief, perhaps like the modern Andes ${ }^{50}$, with deep valleys between mountain ranges. The interval in the Lunpola Basin characterized by ice-related structures was likely a critical period of transition from an intramontane basin surrounded by prominent mountain ranges to the vast proto-Tibetan Plateau.

\section{Methods}

A total of 67 samples were collected and subjected to XRD analysis to determine their bulk mineralogical composition (Supplementary Fig. 3; Supplementary Table 1).

The clay mineralogy of the same samples was investigated after standard preparation techniques ${ }^{51}$. XRD and clay mineralogy analyses were conducted with a Rigaku Ultima IV diffractometer at the Chengdu Land Micro Structure Quality Testing Technology Service Co. Ltd, Sichuan, China. Petrographic and scanning electron microscopy observations were conducted of the ice-related structures in thin-section. Whole-rock geochemical analyses, including major and trace elements, were undertaken in the Wuhan Sample Solution Analytical Technology Co. Ltd., Wuhan, China (Supplementary Table 1 and 2).

Stable carbon and oxygen isotope analyses were carried out on 67 samples (Supplementary Fig. 9; Supplementary Table 3) using a 100-400 $\mu$ g aliquot of each sample. Stable isotope analyses were conducted with a Thermo-Finnigan MAT-253 mass spectrometer at the Nanjing Institute of Geology and Paleontology, Chinese Academy of Sciences, Nanjing, China. The long-term reproducibility of these analyses is $< \pm 0.1 \%$ o $(1 \sigma)$. The analytical precisions for $\delta^{13} \mathrm{C}_{\text {carb }}$ and $\delta^{18} \mathrm{O}_{\text {carb }}$ are $\pm 0.04 \%$ o and $\pm 0.08 \%$, respectively. The lack of a correlation between $\delta^{13} \mathrm{C}$ and $\delta^{18} \mathrm{O}\left(r^{2}=0.0679\right)$ is indicative of a diagenetic overprint (Supplementary Table 3).

Youngest detrital zircon U-Pb ages were used to obtain precise maximum depositional ages of the studied section. Two hundred and eight randomly selected zircon grains were dated at the Wuhan Sample Solution Analytical Technology Co. Ltd., Wuhan, China (Supplementary Table 4). The operating conditions for the laser ablation system and inductively coupled plasma mass spectrometer, as well as the data reduction procedures, are the same as those described by Ref. ${ }^{52}$.

In addition, 14 rock samples were subjected to palynological analysis after the standard preparation techniques of Ref. ${ }^{53}$. Slides were prepared by mounting the resulting residue in glycerin jelly, and then counted under a microscope at $\times 20$ magnification (Supplementary Fig. 9). Palynological analyses and microscopic observations were conducted at the Nanjing Institute of Geology and Paleontology, Chinese Academy of Sciences, Nanjing, China.

\section{Declarations}




\section{Acknowledgements}

We thank K. Zhao, H. Huang, J. Chen and X. Lang. for helpful discussions and Y. Chen, J. Wu and W. Xu for their assistance in the field. This research was financially funded by the National Natural Science Foundation of China (Grant No. 41972115 and No. 41772105).

\section{Author information}

Affiliations

State Key Laboratory of Oil and Gas Reservoir Geology and Exploitation, Chengdu University of Technology, 610059 Chengdu, China

Guoqing Xia, Chihua Wu, Xin Jin, Qiushuang Fan \& Zhiqiang Shi

Institute of Sedimentary Geology, Chengdu University of Technology, Chengdu 610059, China

Guoqing Xia, Chihua Wu, Xin Jin \& Zhiqiang Shi

Calle Mascaraque, 48, 2_A, Madrid, 28044, Spain

Juan Pedro Rodríguez-López

Geology Department, Faculty of Science, Minia University, 61519 Minia, Egypt

Ahmed Mansour

College of Resources and Environmental Engineering, Mianyang Normal University, 621006 Mianyang, China

Gaojie Li

Institute of Geomechanics, Chinese Academy of Geological Sciences, 100081 Beijing, China

Pei Junlin

\section{Contributions}

G.X., C.W., J.P.R. jointly designed the study. G.X. collected the samples and analysed the data; G.X., C.W. and A.M. wrote the original draft. J.P.R. conducted recovered IISS description. J.P.R., C.W. and A.M. revised the draft versions. All authors contributed to review and editing of submitted manuscript.

\section{Corresponding authors}

Correspondence to Chihua Wu. 
Dr.Wu Chihua, wuchi-hua@foxmail.com, State Key Laboratory of Oil and Gas Reservoir Geology and Exploitation, Chengdu University of Technology, 610059 Chengdu, China; Institute of Sedimentary Geology, Chengdu University of Technology, Chengdu 610059, China

\section{Ethics declarations}

Competing interests

The authors declare no competing interests.

\section{References}

1. Hutchinson, D. et al. The Eocene-Oligocene transition: A review of marine and terrestrial proxy data, models and model-data comparisons. Clim. Past 17, 269-315 (2021).

2. Zachos, J. C. Trends. Rhythms, and Aberrations in Global Climate $65 \mathrm{Ma}$ to Present. Science 292, 686-693(2001).

3. Tripati, A., Backman, J., Elderfield, H. \& Ferretti, P. Erratum: Eocene bipolar glaciation associated with global carbon cycle changes. Nature 438, 122 (2005).

4. Darby, D. A. Ephemeral formation of perennial sea ice in the Arctic Ocean during the middle Eocene. Nat. Geosci. 7, 210-213 (2014).

5. Tripati, A. \& Darby, D. Evidence for ephemeral middle Eocene to early Oligocene Greenland glacial ice and pan-Arctic sea ice. Nat. Commun. 9, 1038 (2018).

6 . Ao, H. et al. Orbital climate variability on the northeastern Tibetan Plateau across the EoceneOligocene transition. Nat. Commun. 11, 5249 (2020).

7. Larsen, H. C. et al. Seven Million Years of Glaciation in Greenland. Science 264, 952-955 (1994).

8. Eldrett, J. S., Harding, I. C., Wilson, P. A., Butler, E. \& Roberts, A. P. Continental ice in Greenland during the Eocene and Oligocene. Nature 446, 176-179 (2007).

9. Stickley, C. E. et al. Evidence for middle Eocene Arctic sea ice from diatoms and ice-rafted debris. Nature 460, 376-379 (2009).

10. Coxall, H. K., Wilson, P. A., Pälike, H., Lear, C. H. \& Backman, J. Rapid stepwise onset of Antarctic glaciation and deeper calcite compensation in the Pacific Ocean. Nature 433, 53-57 (2005).

11. Cramer, B., Miller, K., Barrett, P. \& Wright, J. Late Cretaceous-Neogene trends in deep ocean temperature and continental ice volume: Reconciling records of benthic foraminiferal geochemistry $\left(\delta^{18} \mathrm{O}\right.$ and $\left.\mathrm{Mg} / \mathrm{Ca}\right)$ with sea level history. J. Geophys. Res. 116, 12023 (2011).

12. Stickley, C. et al. Variability in the length of the sea ice season in the Middle Eocene Arctic. Geology 40, 727-730 (2012).

13. Nesbitt, H. W. \& Young, G. M. Early Proterozoic climates and plate motions inferred from major element chemistry of lutites. Nature 299, 715-717 (1982).

14. McLennan, S. M. Weathering and Global Denudation. The Journal of Geology 101, 295-303 (1993). 
15. Wang, Y. S., Zhang, S. Q. \& Xie, Y. H. Report of 1:250,000 regional geological survey in Angdaercuo. Wuhan: China University of Geosciences Press, (2012).

16. Kapp, P., Yin, A., Harrison, T. \& Ding, L. Cretaceous-Tertiary shortening, basin development, and volcanism in central Tibet. Geol. Soc. Am. Bull. 117, 865-878 (2005).

17. Dupont-Nivet, G. et al. Tibetan plateau aridification linked to global cooling at the Eocene-Oligocene transition. Nature 445, 635-638 (2007).

18. Licht, A. et al. Asian monsoons in a late Eocene greenhouse world. Nature 513, 501-506 (2014).

19. Molnar, P., England, P. \& Martinod, J. Mantle dynamics, uplift of the Tibetan Plateau, and the Indian Monsoon. Rev. Geophys. 31, 357-396 (1993).

20. Wang, C. S. et al. Constraints on the early uplift history of the Tibetan Plateau. Proc. Natl Acad. Sci. USA 105, 4987 (2008).

21. Boos, W. R. \& Kuang, Z. Dominant control of the South Asian monsoon by orographic insulation versus plateau heating. Nature 463, 218-222 (2010).

22. An, Z. S., Kutzbach, J. E., Prell, W. L. \& Porter, S. C. Evolution of Asian monsoons and phased uplift of the Himalaya-Tibetan plateau since Late Miocene times. Nature 411, 62-66 (2001).

23. Guo, Z. T. et al. Onset of Asian desertification by 22 Myr ago inferred from loess deposits in China. Nature 416, 159-163 (2002).

24. Selleck, B., Carr, P. \& Jones, B. A Review and Synthesis of Glendonites (Pseudomorphs after Ikaite) with New Data: Assessing Applicability as Recorders of Ancient Coldwater Conditions. J. Sediment. Res. 77, 980-991 (2007).

25. Swainson, I. \& Hammond, R. P. Ikaite, $\mathrm{CaCO}_{3} \cdot 6 \mathrm{H}_{2} \mathrm{O}$ : Cold comfort for glendonites as paleothermometers. Am. Mineral. 86, 1530-1533 (2001).

26. Zhou, X. L. et al. Ikaite Abundance Controlled by Porewater Phosphorus Level: Potential Links to Dust and Productivity. Journal of Geology A Semi Quarterly Magazine of Geology \& Related Sciences 123, 269-281 (2015).

27. Rysgaard, S. et al. Ikaite crystals in melting sea ice - Implications for $\mathrm{pCO}_{2}$ and pH levels in Arctic surface waters. The Cryosphere 6, 901-908 (2012).

28. Scher, H., Bohaty, S., Zachos, J. C. \& Delaney, M. Two-stepping into the icehouse: East Antarctic weathering during progressive ice-sheet expansion at the Eocene-Oligocene Transition. Geology 39, 383-386 (2011).

29. Mottin, T. E., Vesely, F. F., de Lima Rodrigues, M. C. N., Kipper, F. \& de Souza, P. A. The paths and timing of late Paleozoic ice revisited: New stratigraphic and paleo-ice flow interpretations from a glacial succession in the upper Itararé Group (Paraná Basin, Brazil). Palaeogeogr. Palaeoclimatol. Palaeoecol. 490, 488-504 (2018).

30. Rodríguez-López, J. P., Van Vliet-Lanoë, B., López-Martínez, J. \& Martín-García, R. Scouring by rafted ice and cryogenic patterned ground preserved in a Palaeoproterozoic equatorial proglacial lagoon succession, eastern India, Nuna supercontinent. Mar. Petrol. Geol. 123, 104766 (2021). 
31. Pagani, M., Zachos, J. C., Freeman, K. H., Tipple, B. \& Bohaty, S. Marked Decline in Atmospheric Carbon Dioxide Concentrations During the Paleogene. Science 309, 600 (2005).

32. Retallack, G. J. Greenhouse crises of the past 300 million years. Geol. Soc. Am. Bull 121, 1441-1455 (2009).

33. Pearson, P. N., Foster, G. L. \& Wade, B. S. Atmospheric carbon dioxide through the Eocene-Oligocene climate transition. Nature 461, 1110-1113 (2009).

34. Zhang, Y. G., Pagani, M., Liu, Z., Bohaty, S. M. \& DeConto, R. A 40-million-year history of atmospheric $\mathrm{CO}_{2}$. Philosophical Transactions of the Royal Society A: Mathematical, Physical and Engineering Sciences 371, 20130096 (2013).

35. Tremblin, M., Hermoso, M. \& Minoletti, F. Eocene-Oligocene sea surface temperature and $\mathrm{pCO}_{2}$ estimates. Proc. Nat/ Acad. Sci. USA 113, 11782-11787 (2016).

36. Gradstein, F. M. \& Ogg, J. G. in Geologic Time Scale 2020 (eds.Gradstein, F. M., Ogg, J. G., Schmitz, M. D. \& Ogg, G. M.) 21-32 (Elsevier, 2020).

37. Fagel, N. in Developments in Marine Geology Vol. 1 (eds.Hillaire Marcel, C. \& De Vernal, A.) 139-184 (Elsevier, 2007).

38. Fang, X. M. et al. Revised chronology of central Tibet uplift (Lunpola Basin). Sci. Adv. 6, 1-10 (2020).

39. Hren, M. T. et al. Terrestrial cooling in Northern Europe during the Eocene-Oligocene transition. Proc. Natl Acad. Sci. USA 110, 7562 (2013).

40. McCormack, J., Nehrke, G., Jöns, N., Immenhauser, A. \& Kwiecien, O. Refining the interpretation of lacustrine carbonate isotope records: Implications of a mineralogy-specific Lake Van case study. Chem. Geol. 513, 167-183 (2019).

41. Gallagher, S. J. et al. Eocene to Oligocene high paleolatitude neritic record of Oi-1 glaciation in the Otway Basin southeast Australia. Glob. Planet. Chang. 191, 103218 (2020).

42. Rowley, D. B. \& Currie, B. S. Palaeo-altimetry of the late Eocene to Miocene Lunpola basin, central Tibet. Nature 439, 677-681 (2006).

43. Spicer, R. A. Tibet, the Himalaya, Asian monsoons and biodiversity - In what ways are they related? Plant Diversity 39, 233-244 (2017).

44. Rodríguez-López, J. P. \& Wu, C. H. Recurrent deformations of aeolian desert dunes in the cretaceous of the South China Block: Trigger mechanisms variability and implications for aeolian reservoirs. Mar. Petrol. Geol. 119, 104483 (2020).

45. Su, T. et al. No high Tibetan Plateau until the Neogene. Sci. Adv. 5, v2189 (2019).

46. Norris, R. D. et al. Sliding Rocks on Racetrack Playa, Death Valley National Park: First Observation of Rocks in Motion. PLoS One 9, e105948 (2014).

47. Hock, R. et al. High Mountain Areas. (ed.H. O. Pörtner, D. C. R. V.) 131-202 (IPCC - Intergovernmental Panel on Climate Change, 2019).

48. Wu, F. X., Miao, D. S., Chang, M., Shi, G. L. \& Wang, N. Fossil climbing perch and associated plant megafossils indicate a warm and wet central Tibet during the late Oligocene. Sci. Rep.-UK 7, 878 
(2017).

49. Su, T. et al. A Middle Eocene lowland humid subtropical "Shangri-La" ecosystem in central Tibet. Proc. Natl Acad. Sci. USA 117, 32989 (2020).

50. Ding, L. et al. The Andean-type Gangdese Mountains: Paleoelevation record from the PaleoceneEocene Linzhou Basin. Earth Planet. Sc. Lett. 392, 250-264 (2014).

51. Moore, D. M. \& Reynolds, R. C. X-ray diffraction and the identification and analysis of clay minerals. Sample Preparation Techniques for Clay Minerals, 204-226 (1997).

52. Zong, K. Q. et al. The assembly of Rodinia: The correlation of early Neoproterozoic (ca. 900Ma) highgrade metamorphism and continental arc formation in the southern Beishan Orogen, southern Central Asian Orogenic Belt (CAOB). Precambrian Res. 290, 32-48 (2017).

53. Wood, G. D., Gabriel, A. M. \& Lawson, J. C. Chapter 3. Palynological techniques-processing and microscopy. In. Jasonius, J. and McGregor, D. C. eds., Palynology: Principles and Application. American Association of Stratigraphic Palynologists Foundation 1, 29-50 (1996).

\section{Figures}



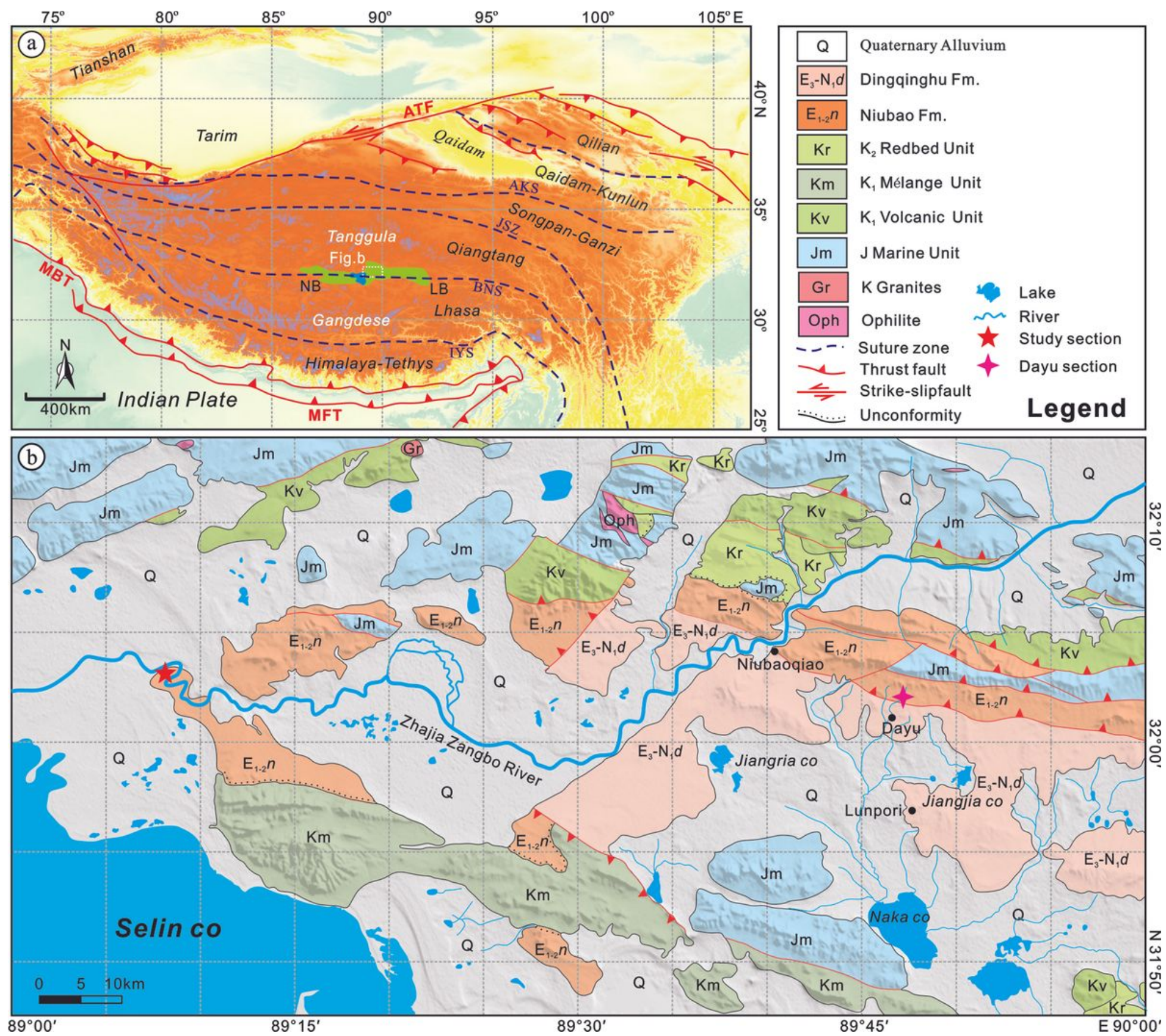

Figure 1

Location of the study area, Lunpola basin in central Tibet, southwestern China. a, Major terranes of the Tibetan Plateau. b, Geological map of the western Lunpola basin (modified from ref. 15). 


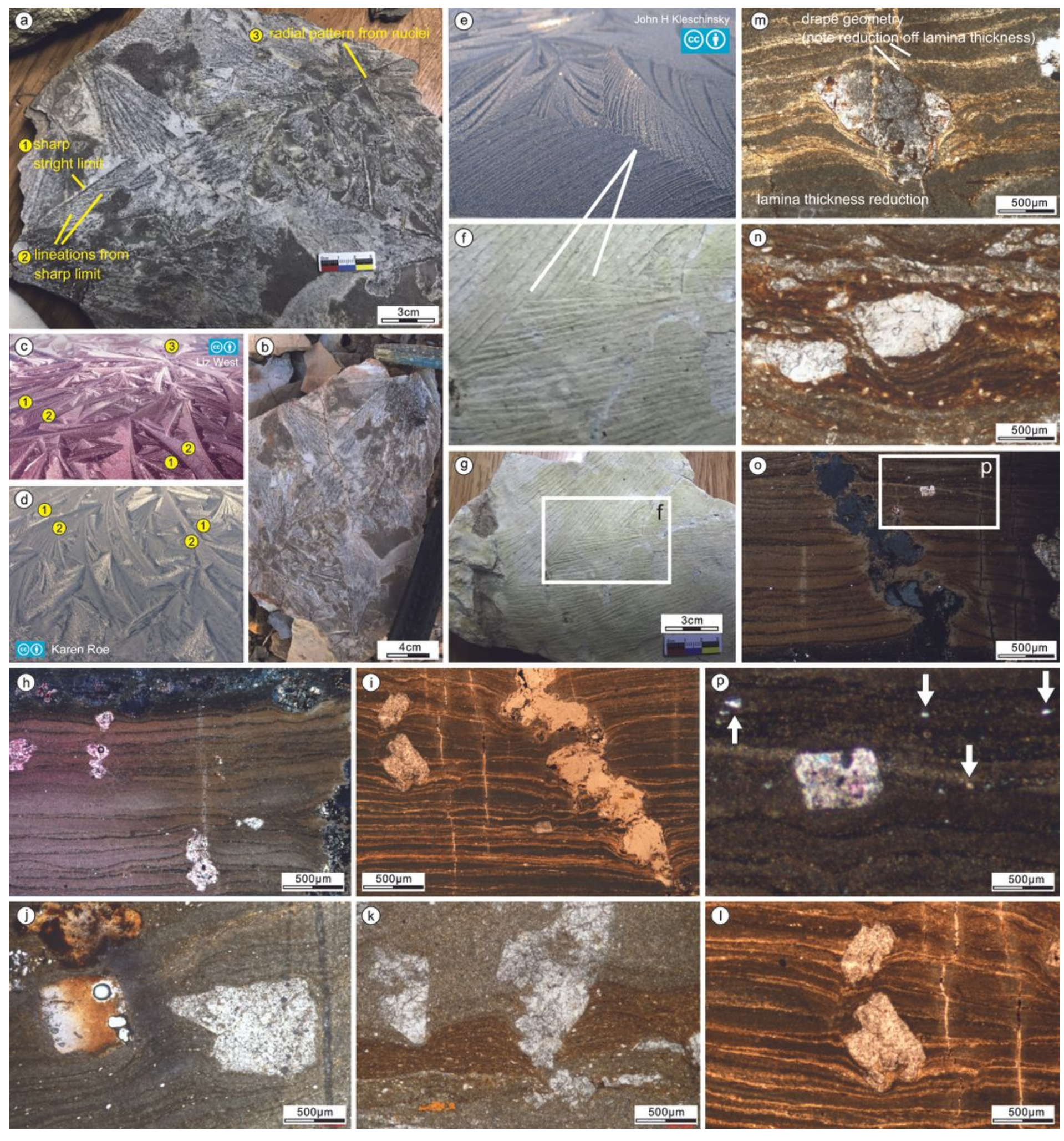

\section{Figure 2}

Ice-related structures in the Nuibao Formation of the Lunpola Basin and their similar modern ice crystal and frost marks. a-b, Eocene Frost marks. c-d, Modern ice crystal marks. e, Modern frost structures. f-g, Eocene frost marks. h-l, Eocene glendonite exhibiting displacive, stellate, and rhombic features. $\mathrm{m}-\mathrm{p}$, Eocene ice-rafted debris. More details for the source of Figs. 2 c-e can be seen in SI. 


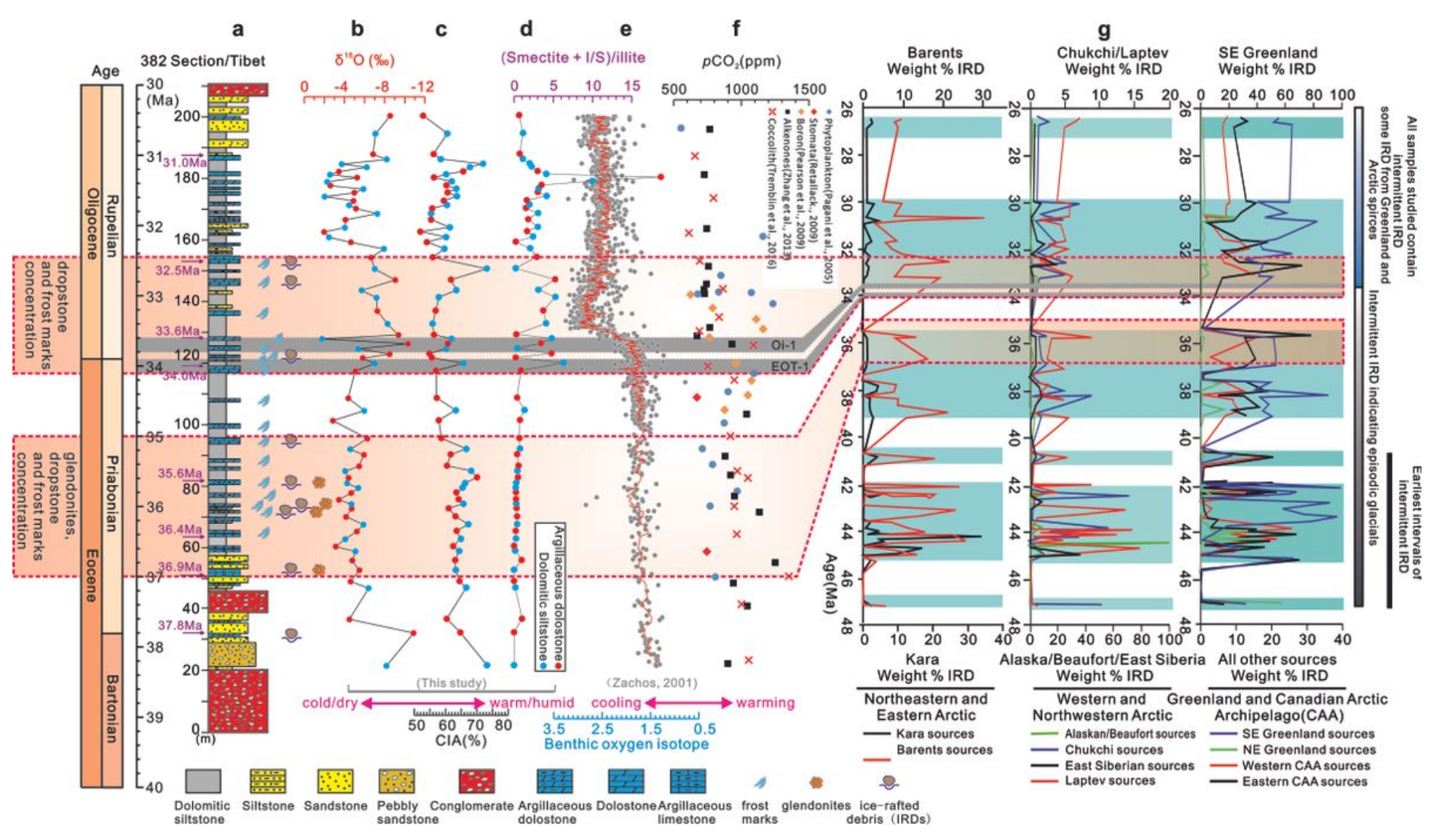

Figure 3

Summary of various paleoclimate proxies in the Eocene-Oligocene. a, Lithostratigraphy and stratigraphic range of the ice-related structures in the studied section. b-d, $\delta 180$ data, chemical index of alteration values, and clay mineralogy of the Niubao Formation, Lunpola Basin, respectively. e, Global $\delta 180$ record from benthic foraminifera2. $\mathrm{f}$, Atmospheric $\mathrm{CO} 2$ content during the late Eocene-early Oligocene31-35. g, Correlation of ice-related structures in the Nuibao Formation on the Tibetan Plateau (blue) with those from Greenland and the Arctic region3-5, showing their significant correlation in two main intervals. The geological timescale follows that of GTS202036. 


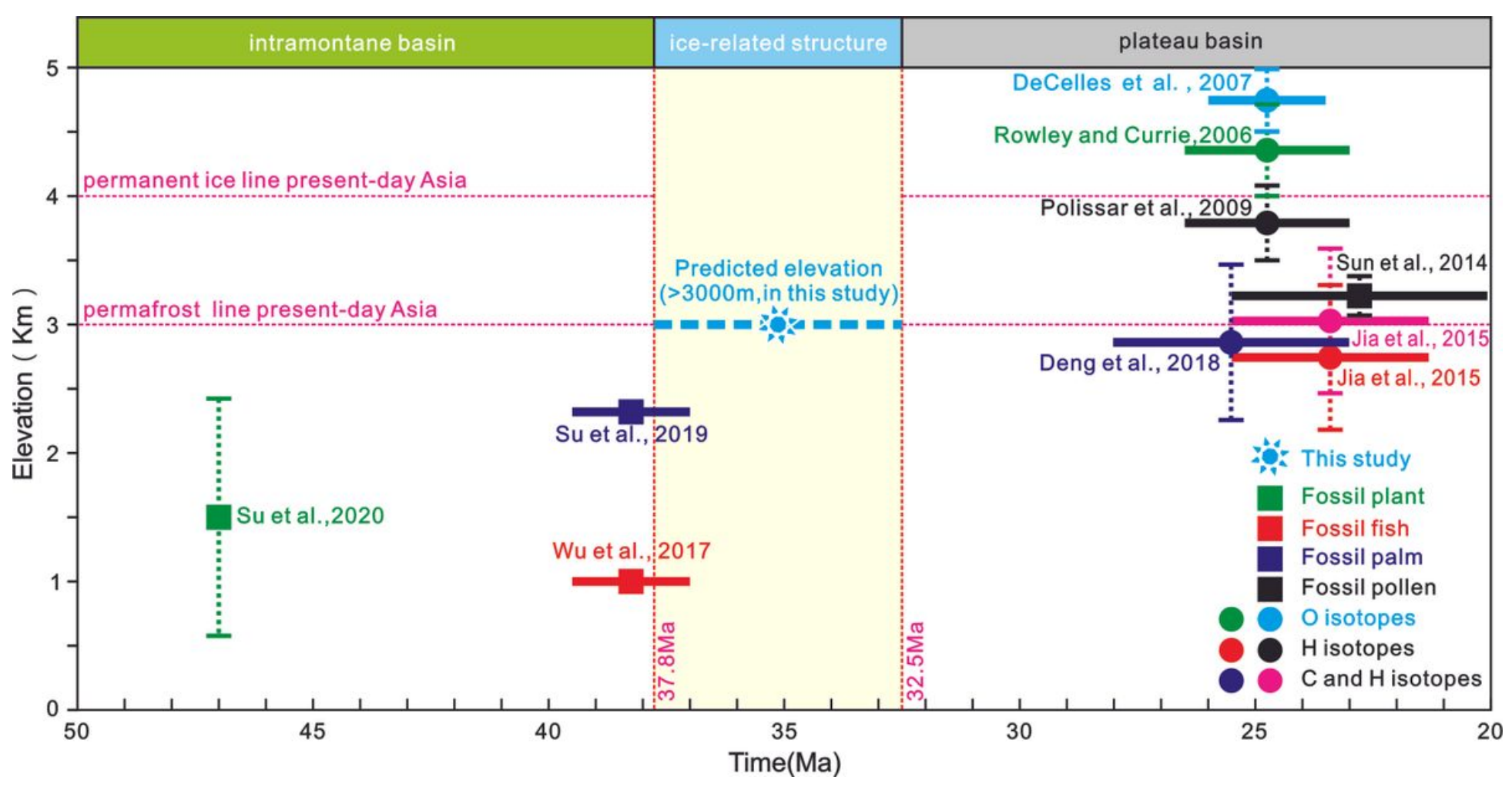

Figure 4

Plot showing the inferred elevation changes of the Lunpola-Nima basins over time, based on geochemical, isotopic, and fossil data (Ref. see SI).

\section{Supplementary Files}

This is a list of supplementary files associated with this preprint. Click to download.

- Supplementarytable1BulkMineralsinthe382sectionintheLunpolaBasinnew.xlsx

- Supplementarytable2ClayMineralsandtraceelementalratiosinthe382sectionintheLunpolaBasin.xlsx

- Supplementarytable3Carbonandoxygenisotopedateofthe382section.xlsx

- Supplementarytable4LAICPMSUPbagesofzirconsfrom382section.xIsx

- Supplementarytable5Bulkrockgeochemistrydataforthe382sample.xlsx

- SupplementaryMaterialicerelatedstructuresfromtheQinghaiTibetanPlateau.docx 